\title{
A study for optimum utilization of the Damodar water resources
}

\author{
BASAWAN SINHA* and P RAMAKRISHNA RAO $\dagger$ \\ * Central Flood Forecasting, Central Water Commission, "Kamata Sadan", 427/c, East \\ Borning, Canal Road, Patna 800001 , India \\ † Central Water Commission, Room 514, Sewa Bhavan, Ramakrishnapuram, New Delhi \\ 110066 , India
}

\begin{abstract}
The study describes the existing and proposed water resources development in the Damodar river basin and the systems study carried out for estimating the consequences of implementing a proposed set of management and development measures. A simulation model was considered appropriate for the study and a computer program developed by the Us Army Corps of Engineers was used. The results of various simulation runs are discussed. The analysis of results have indicated that an integrated operation of all reservoirs on the Damodar system, both existing and proposed, would help in maximization of utilisation and benefits. It is also concluded that a simulation model would help not only the long range planning but also the day-to-day operation.
\end{abstract}

Key Words. River basin development; integrated operation; simulation model.

\section{Introduction}

The wandering and capricious Damodar rises in the hills of Chhotanagpur at an elevation of 2000 feet, and after flowing for 180 miles in Bihar, enters the deltaic plains of West Bengal and ultimately joins the Hooghly. The total drainage area is 8500 miles $^{2}$, of which 6960 miles $^{2}$ are the catchment of the upper Damodar, just below its confluence with the Barakar. Figure 1 shows the region through which the river flows. The river used to cause serious floods in its lower reaches lying in West Bengal. Voorduin (1945) of the Tennessee Valley Authority (TVA) prepared a preliminary memorandum on the unified development of the Damodar river, and the Damodar Valley Corporation (DVC) was set up in 1948 to implement schemes for integrated and coordinated development of the Damodar Basin.

Voorduin's plan of development of the water resources of the valley envisaged construction of seven storage dams across the Damodar and its tributaries at Tilaiya, Konar, Maithon, Panchet, Bokaro, Balpahari and Aiyar; a diversion dam at Bermo and a barrage at Durgapur with a canal network system. This development was to be carried out in two stages. The first stage was to cover the construction of four dams at Tilaiya, Konar, Maithon and Panchet and the barrage with canal system at Durgapur (figure 2). Construction of the remaining four dams was included in the second stage. The first stage was completed in 1958 , and the second stage has not yet been implemented.

Subsequently, a dam at Tenughat on the Damodar river has been constructed by the Bihar Government. This envisaged utilization of 900 cusecs all the year round for

Conversion table

1 inch $=2.54 \mathrm{~cm} ; 1$ foot $=0.3048 \mathrm{~m} ; 1$ mile $=1.609 \mathrm{~km} ; 1$ mile $=2.59 \mathrm{~km}^{2} ; 1$ acre $=0.405 \mathrm{ha} ; 1$ acre foot $=0.1234$ ha $\mathrm{m} ; 1$ cusec $=0.02832$ cumec. 


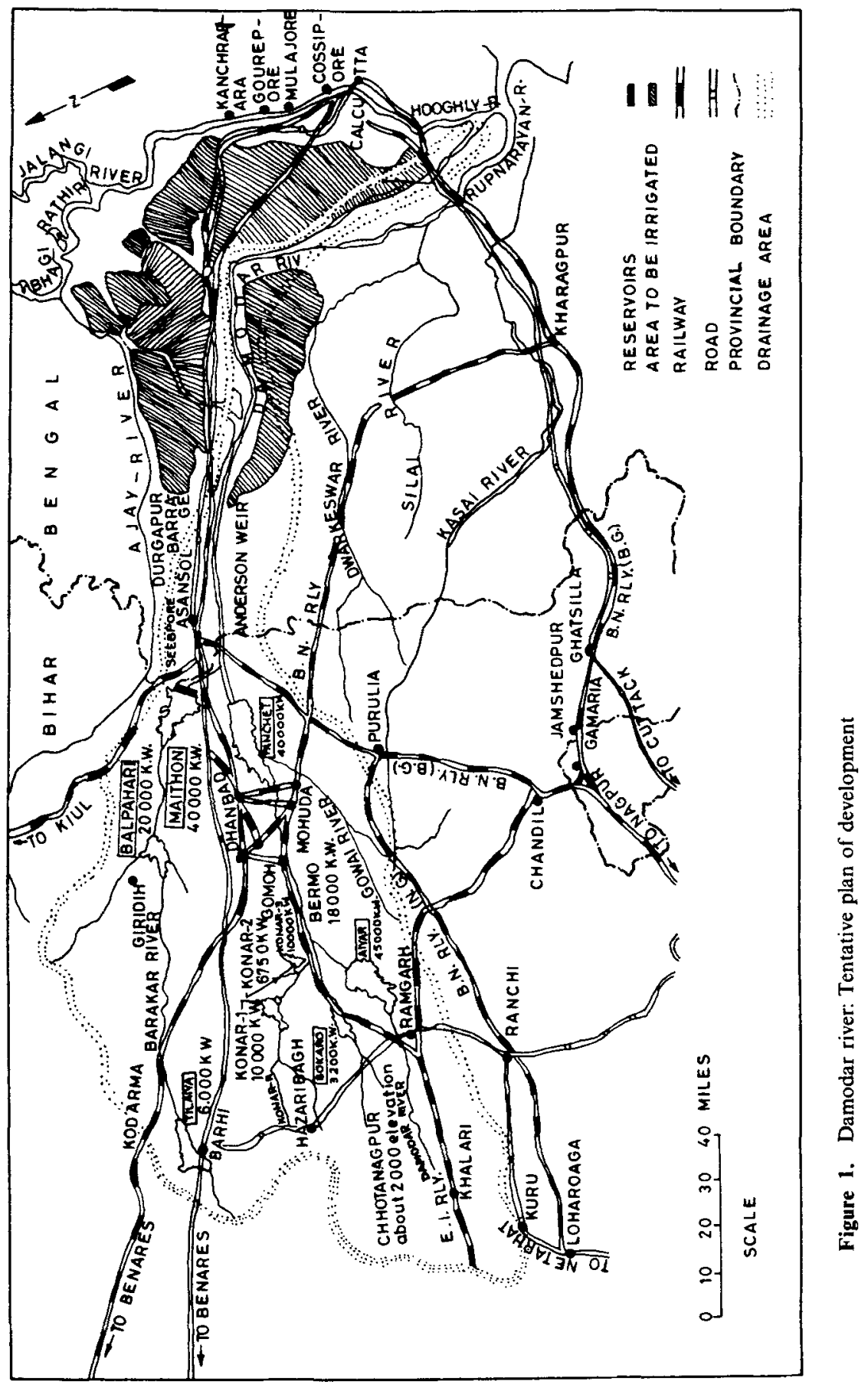




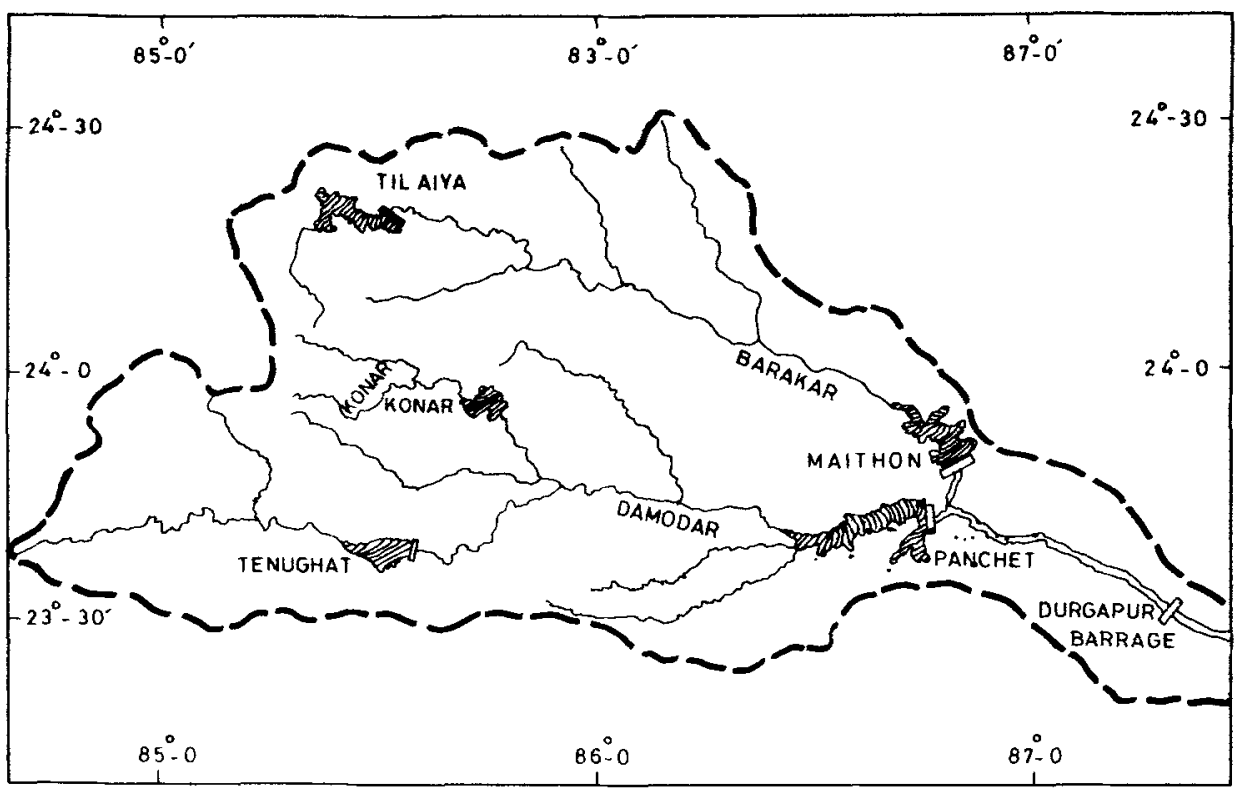

Figure 2. Damodar valley reservoirs

irrigation and industrial water supply. Upstream of this dam, yet another small dam to control about 100 miles $^{2}$ was constructed by the Bihar State Electricity Board to meet the requirements of Pathrathu Thermal Power Station. The Government of Bihar has also prepared some major, medium and minor schemes for utilization of the Damodar waters in the upper reaches for irrigation and industrial uses. This plan of utilization by Bihar includes the use of waters from the existing Konar and Tilaiya dams of DvC. Salient features of existing major projects in the Damodar Valley are given in table 1.

Voorduin's original plan of development provided for a total storage of 4.68 million acre feet (MAF) in seven storage dams, of which $2.915 \mathrm{MAF}$ was earmarked for moderating floods. Against this, only four dams with a gross storage of $2.92 \mathrm{MAF}$ were built in the first stage, out of which $1.52 \mathrm{MAF}$ is the flood storage; $0.97 \mathrm{MAF}$ is conservation storage and 0.43 MAF is the silt storage. But the whole flood storage of 1.52 MAF is not available as yet due to non-acquisition of land in the Maithon and Panchet reservoirs beyond RL (reduced level) 495 and RL 425 respectively. As a result, the effective flood storage at present is only $0.68 \mathrm{MAF}$.

\section{Surface water resources in the basin}

\subsection{Water utilization}

According to the regulations issued by the Central Water Commission (1969), the principal requirements for stored waters are kharif irrigation, power generation and flushing doses during the monsoon season (June to October), and rabi irrigation, navigation, power generation and water supply for industrial and domestic uses during the non-monsoon season (November to June). 
Table 1. Salient features of the Damodar valley

\begin{tabular}{|c|c|c|c|c|c|}
\hline $\begin{array}{l}\text { Name of dam and } \\
\text { river stream }\end{array}$ & $\begin{array}{l}\text { Catchment } \\
\text { area }\left(\text { miles }^{2}\right)\end{array}$ & $\begin{array}{l}\text { Dead storage } \\
\text { (acre feet) }\end{array}$ & $\begin{array}{l}\text { Conservation } \\
\text { storage } \\
\text { (acre feet) }\end{array}$ & $\begin{array}{c}\text { Flood } \\
\text { storage } \\
\text { (acre feet) }\end{array}$ & $\begin{array}{c}\text { Installed } \\
\text { capacity } \\
\text { of power } \\
\text { house }(\mathrm{MW})\end{array}$ \\
\hline Tilaiya: Barakar & 380 & 60,680 & 114,800 & 143,900 & 4 \\
\hline Maithon: Barakar & 2430 & 168,090 & 495,540 & 446,370 & $3 \times 20$ \\
\hline $\begin{array}{ll}\text { Konar: } & \text { Konar- } \\
& \text { tributary } \\
& \text { of Damodar }\end{array}$ & 385 & 49,530 & 178,770 & $\begin{array}{c}216.370^{*} \\
44,200\end{array}$ & 一. \\
\hline Panchet: Damodar & 4234 & 148,060 & 184,930 & $\begin{array}{l}881,000 \\
277,000^{*}\end{array}$ & $1 \times 40$ \\
\hline $\begin{array}{l}\text { Total for } \\
\text { Dve }\end{array}$ & 7430 & 426,400 & 974,000 & $\begin{array}{r}1,515,500 \\
681,470^{*}\end{array}$ & \\
\hline Tenughat: Damodar & 1730 & 170,000 & 621,100 & - & - \\
\hline
\end{tabular}

- Flood storage available with land acquisition upto RL 495 and RL 425 in Maithon and Panchet reservoirs respectively; RL-reduced level

The requirement of kharif irrigation has been worked out on the basis suggested by the Water Management Division, Ministry of Food and Agriculture (table 2). The overall requirement works out to $1.792 \mathrm{MAF}$, which includes $0.579 \mathrm{MAF}$ during October. According to the regulation schedule, the reservoirs have to be operated such that they are full at the monsoon storage level after meeting all the requirements. The conservation storage available in all the four dams of the DVC system is $0.974 \mathrm{MAF}$ and it

Table 2. Monthly requirements of water for kharif irrigation (June to October).

\begin{tabular}{|c|c|c|c|c|c|}
\hline \multirow{2}{*}{ Month } & \multirow{2}{*}{\multicolumn{2}{|c|}{$\begin{array}{c}\text { Irrigation } \\
\text { requirement } \\
\text { of the crops (in inches) } \\
\text { on the basis suggested } \\
\text { by Ministry of } \\
\text { Food \& Agriculture }\end{array}$}} & \multicolumn{2}{|c|}{$\begin{array}{l}\text { Irrigation } \\
\text { requirement } \\
\text { at canal head }\end{array}$} & \multirow[t]{2}{*}{$\begin{array}{c}\text { Total requirement } \\
\text { at canal head } \\
10^{3} \text { acre } \mathrm{ft} .\end{array}$} \\
\hline & & & Inches & reet & \\
\hline June & & 0.2 & 0.286 & 0.024 & 24 \\
\hline July & & 40 & $5 \cdot 714$ & 0.476 & 467 \\
\hline August & 13 & $2 \cdot 2$ & $3 \cdot 143$ & 0.262 & 255 \\
\hline September & $2 \cdot 6$ & 4.0 & 5.714 & 0.476 & 467 \\
\hline October & $8 \cdot 2$ & $5 \cdot 0$ & $7 \cdot 143$ & $0 \cdot 595$ & 579 \\
\hline Total & $32 \cdot 1$ & 15.4 & $22 \cdot 0(x)$ & 1.833 & 1792 \\
\hline
\end{tabular}

Notes;

1. Irrigated area during kharif season $=973 \times 10^{3}$ acres.

2. Canal and outlet efficiencies are assumed to be $82^{\circ}, 0$ and $85^{\circ}$, i.e. overall efficiency during kharif is $70 \%$. 3. Monthly water requirements suggested by Water Management Division (column 2) have been suitably modified (see column 3) allowing for seed beds in June and accounting for uneven distribution of rainfall during the monsoon. 
is earmarked for utilization in the following manner:

\begin{tabular}{lcc} 
Kharif irrigation & & MAF \\
Navigation & 0.40 \\
Industrial & & 0.17 \\
Releases below Durgapur & 0.34 \\
Rabi irrigation & & 0.04 \\
& & 0.07 \\
The above requirement is met as follows: & & 1.02 \\
Monsoon storage & & MAF \\
Evaporation losses & $(-)$ & 0.974 \\
Water available from storage & & 0.214 \\
Utilization from dead storage of Panchet & & 0.76 \\
Utilization of dry season inflow & & 0.10 \\
& & 0.16 \\
\hline
\end{tabular}

The overall annual utilization of water in the Dvc system works out to about $2.5 \mathrm{MAF}$, the monthly distribution of which is given in table 3 .

\subsection{Water availability}

According to the Regulation Manual (1969) for DvC reservoirs, the estimated average annual run-offs at different dams are:

\begin{tabular}{ll} 
Tilaiya & MAF \\
Maithon & 0.35 \\
Konar & 2.12 \\
Panchet & 0.45 \\
\hline
\end{tabular}

Observed discharge data (Banerjee 1975) at all these sites are availatle for the last 18 years. Analysis of these data shows that there is wide variation in the annual yields. The minimum and maximum yields on record are given in table 4.

\section{The problem}

At present the Damodar system has a group of four reservoirs with a terminal barrage at Durgapur in operation for over twenty years and the one at Tenughat functioning for five years. The hydrological data available indicate that $75 \%$ dependable annual yield at Durgapur is of the order of $4.9 \mathrm{MAF}$ and the mean annual inflow average for the period of operation (1956-73) is as high as 6.18 MAF. Against this, the present utilisation of water for the DVC system is only $2.50 \mathrm{MAF}$. And, yet occasionally a shortfall in irrigation and/or hydel power supply occurs. This can be obviously attributed to either inadequacy in storage capacities (including carryover storage) or deficiency in 
Table 3. Water requirements

\begin{tabular}{|c|c|c|c|c|c|c|c|c|c|c|c|c|}
\hline \multirow[b]{2}{*}{ Purpose } & \multicolumn{12}{|c|}{ Diversions/releases $\left(10^{3}\right.$ acre foet $)$} \\
\hline & Jun. & Jul. & Aug. & Sept. & Oct. & Nov. & Dec. & Jan. & Feb. & Mar. & Apr. & May \\
\hline \multicolumn{13}{|l|}{ Irrigation } \\
\hline Kharif & 24 & 467 & 255 & 467 & 579 & - & - & - & - & - & - & - \\
\hline Rabi & - & - & - & - & - & 13 & 13 & 14 & 13 & 13 & 3 & - \\
\hline Industrial & 28 & 29 & 29 & 28 & 29 & 28 & 29 & 29 & 27 & 29 & 28 & 29 \\
\hline Mandatory & - & - & 一 & - & - & 6 & 6 & 6 & 6 & 6 & 6 & 6 \\
\hline Navigation & 24 & - & 一 & - & - & 24 & 25 & 24 & 24 & 24 & 25 & 25 \\
\hline Losses & 6 & - & - & - & $\ldots$ & 7 & 7 & 7 & 7 & 7 & 7 & 6 \\
\hline Total & 82 & 496 & 284 & 495 & 608 & 78 & 80 & 80 & 77 & 80 & 69 & 66 \\
\hline (Cusecs) & 1367 & 8000 & 4581 & 8250 & 9806 & 1300 & 1290 & 1290 & 1375 & 1290 & 1150 & 1065 \\
\hline
\end{tabular}

Note: The above water requirements are exclusive of the evaporation losses from the reservoir.

Monsoon period (June to Sept.) $=1357 \times 10^{3}$ acre feet

Non-monsoon period (October) $=608 \times 10^{3}$ acre feet

(November to May) $=530 \times 10^{3}$ acre feet

$2495 \times 10^{3}$ acre feet

Table 4. Annual runoff at different dam sites (value in thousands)

\begin{tabular}{lcc}
\hline $\begin{array}{l}\text { Name of } \\
\text { dam site }\end{array}$ & $\begin{array}{c}\text { Minimum on record } \\
\text { (in acre feet) } \\
(1966-67)\end{array}$ & $\begin{array}{c}\text { Maximum on record } \\
\text { (in acre feet) } \\
(1971-72)\end{array}$ \\
\hline Tilaiya & 64 & 660 \\
Maithon & 655 & 5,009 \\
Konar & 111 & 690 \\
Tenughat & 608 & 2,644 \\
Panchet & 1,108 & 7,351 \\
Durgapur & 1,965 & 15,272 \\
\hline
\end{tabular}

operating rules or both. Then, there is need for increasing utilization which till now is much lower than the firm yield a properly planned system for the basin can provide.

\section{The simulation model}

The study was undertaken with this background and a simulation model was considered more appropriate for estimating the consequences of implementing a proposed set of management and development measures, viz (i) increasing the storage capacities of the Maithon and Panchet dams upto the top of gates; (ii) using a portion of flood storage space for conservation; (iii) abstraction of about half-a-million acreft. of water for upstream use; (iv) utilizing the storage in Konar and Tilaiya dams for consumptive use on the upstream; (v) integrating the regulation of the Tenughat reservoir with the DvC system of reservoirs; (vi) modifying the operating rules for both flood control and water supply; and (vii) determining the operational efficiency of alternative plans of utilization. 
For this purpose, a computer program (No. 723-x6-L 2030) developed at the Hydrologic Engineering Centre, us Army Corps of Engineers (1976) seemed appropriate and hence, has been chosen for the simulation studies. This program performs a multipurpose routing of flows in a reservoir system for upto twelve periods of uniform or varying lengths per year based on varying flow requirements at reservoirs, diversions and downstream control points. It can accommodate power peaking and energy requirements at reservoirs and can assign economic values to all outputs and allocate these in various ways. It can automatically iterate to optimize yield at a specified location.

\section{The system}

\subsection{System components}

There are five basic system components which are generally used by the program to model a reservoir system viz. the system hydrology, reservoirs, control points, power plants and diversions.

5.1a Hydrologic characteristics: The system inflows which are the primary hydrologic components of the programs, are specified by identifying their location (i.e. the control point where they occur), their magnitude and the period when they occur. Incremental local flows are equal to the difference between inflows at adjacent control points. Reservoir evaporation, an important part of the system's water balance computation, is input into the model by- specifying a net evaporation rate (difference between evaporation and rainfall) for each reservoir.

5.1b Reservoir characteristics: Storage, surface area and outlet capacity are specified on 10 reservoir elevations to describe adequately the physical features (area and capacity curves given in the Regulation Manual) of each reservoir necessary to model the storage and release features of the reservoir. To simulate the operation of a reservoir system the operating criteria are expressed in quantitative terms by dividing each reservoir storage into six horizontal levels. The difference between the levels is taken as the zone of potential storage volume. The lowest level corresponds to the bottom of the conservation pool (top of the inactive pool), the second lowest level is the top of the buffer zone, the highest level is the full pool level (top of the flood control), and the second highest level is the top of conservation (bottom of flood control). Additional levels to facilitate individual reservoir operating criteria are specified.

Each reservoir is operated to meet stream flow targets at specified locations in the system. Priority of withdrawals from reservoirs serving the same location is established by specifying additional levels. The highest storage zone is withdrawn first, then the second highest and so on down to the lowest keeping all reservoirs in the system in balance to the extent possible. Other operating criteria specified in the model are initial reservoir storage and spillway surcharge.

5.1c Hydrologic balance: Computations in the model are based on the principle of continuity equation.

5.1d Control point characteristics: Control points, which are not reservoirs, are used to regulate system operation by establishing constraints and targets on streamflow. Both reservoirs and selected locations along the stream network are assigned control point 
numbers. There are three types of controls specified for any stream control point: maximum permissible flow, minimum desired flow and minimum required fow.

5.1e Power plant characteristics: Power plant characteristics which are used in the model to simulate power operations include installed power plant nameplate capacity, maximum plant factor for generation, power plant efficiency, tailwater elevation glus hydraulic loss, overload ratio for the power installation and power load requirements for each plant for each time period.

5.If Diversions: One diversion exists at each control point except at Maithon and the actual flow diverted is specified. Diversion shown at Panchet actually relates to withdrawals above it and below Tenughat.

5.1g Economic evaluation: An economic analysis of the system operation is available at each control point by specifying a functional relationship between a hydrologic quantity such as streamflow, reservoir storage, power generation and the economic value of meeting the hydrologic quantities during a given month. In the present study, however, the economic parameters have not been assigned.

\subsection{System operation}

The simulation model operates by considering the water and power requirements at each pertinent control point in the system in a sequential fashion, beginning at an upstream point and moving in a downstream direction through each river basin. The release required to meet these requirements for all pertinent purposes is determined by evaluating each operational requirement and all physical and operational constraints at each site. Also, an index of the relative state of each reservoir (as a function of reservoir storage) is determined according to the specified operation guides. After the reciuirements have been met at all control points (or shortages declared if upstream water is not available), "system requirements" are examined to determine whether additional water releases for power generation will be needed to satisfy the system power demands If so, the additional needs are proportioned among the reservoirs that have been specified to be available for meeting that system requirement in accordance with the relative state of the reservoirs as evidenced by the indices previously computed. The additional releases are added to the previously computed releases for meeting at-site requirements, and the system and at-site requirements are thus met (or shortages are declared if water is not available). This process is repeated for each period of the study, with the ending state of the reservoirs in the system for the current period being the beginning state for the next period.

Results from the successive applications of these calculations on a period-by-period basis are recorded for all points in the system (including non-reservoirs) by an accounting procedure which accounts for the movement of the water through the system by using the specified relative location of the reservoirs and downstream control points.

For the power plants included in the system, the requirements for the system as a whole as well as the minimum requirements for each plant are specified. During the first search of the system, the minimum power requirement at each plant will be established, and the total generation during the period at each plant will be computed. This total can exceed the minimum required generation if other services call for additional releases from the particular reservoir. 
At the end of the first search, a summary is made of the total power generated and required and of the total power generated and used to satisfy system requirements. If the system requirement has not been satisfied, water levels at those reservoirs where additional generated power could be used for meeting system requirements would then be drawn towards a common storage-balancing level such that the full system requirement is generated. The allocated system requirements are then used in making a second search of the entire system for all purposes.

Since satisfying these additional requirements will usually change releases at many reservoirs, the average head during the second search will be different from the average obtained from the first search and used in the second search. Accordingly, accurate system power (and evaporation) computations require a third complete search of the entire water resource system for each operation period.

\section{Simulation model studies}

There are at present six major reservoirs in operation in the Damodar Basin, four under DVC, the fifth under the Bihar Government departmental control and the sixth under the Bihar State Electricity Board. The three agencies operate the reservoirs, constructed and maintained by them independently. Schemes for utilization of Tilaiya and Konar reservoirs for irrigation in Bihar have been formulated. There is further demand for atleast 0.5 MAF of the Damodar waters in Bihar (upstream of Maithon and Panchet dams), but the proposed schemes are not yet cleared for implementation due to the apprehension that they may adversely affect the existing DVC system, which caters to the needs of irrigation, hydel power, navigation, industrial and drinking water supply, through Tilaiya and Maithon dams on Barakar, Konar and Panchet dams on the Damodar, and Durgapur barrage on the Damodar below the confluence of the Damodar and the Barakar. The present annual utilization of water for the Dvc system is only 2.5 MAF (see the breakdown given in table 3) as against the assessed $75 \%$ dependable yield of $4.9 \mathrm{MAF}$ and $50 \%$ dependable yield of 6.8 MAF at Durgapur. If the inflows from catchments above Tilaiya, Konar and Tenughat are excluded, the corresponding dependable yields at Durgapur would still be 3.4 and $4.8 \mathrm{MAF}$ and that at Maithon-Panchet would be about 2.5 and 3.4 MAF. Therefore, the first set of studies using simulation models is aimed at investigating the effect of the proposed schemes of upstream abstraction on the DVC system. For the sake of simplification, the entire yield from above Tilaiya, Konar and Tenughat dams has been excluded from the total catchment areas of Maithon and Panchet dams. This means that the effective catchment areas at Maithon and Panchet would be reduced to 2010 and 2100 miles $^{2}$ from 2390 and 4215 miles $^{2}$. Monthly yield data as available since 1956 have been utilized for the studies. In the first study, the reservoir capacity and the regulation schedule as at present, have been maintained.

The second set of studies was carried out keeping in view the proposal for acquisition of land up to the top of the gates in Panchet and Maithon dams to increase their effective gross storage capacity from 0.980 to $1 \cdot 11$ MAF in Maithon and from 0.61 to 1.21 MAF in Panchet, i.e. a net increase of 0.73 MAF. In these studies it was proposed that a part of the additional storage likely to be available through further land acquisition, should go for increasing the conservation storage and the rest to flood storage. Lesser flood storage than originally envisaged at Panchet seems justified in view of the fact that 
the Tenughat dam now controls 1730 miles $^{2}$ out of the 4215 miles $^{2}$ of its catchment; and even if there were no specific flood storage earmarked in the Tenughat dam, the system, if operated properly, will provide substantial flood moderation effect at and from Panchet. Two alternatives (studies $2 \cdot 1$ and $2 \cdot 2$ ) have been analysed as indicated in table 5. The results of these studies are tabulated in tables 6,7 and 8 .

The results of simulation (study 1) show that power generation during the monsoon would increase while it would decrease during the non-monsoon months. Further, water scarcity has been experienced in the critical months (July and October) of kharif irrigation in 14 years out of 18 . The monsoon yield has exceeded the requirement and has been spilled. The failures in October and the following July indicate inadequate conservation storage. Also, the failures in October are due to the present regulation policy which specifies water levels to be maintained at full conservation level upto the end of October. Since the overall requirement of water from November to May is of the order of $0.53 \mathrm{MAF}$, it would be advantageous to permit a lower conservation level at the end of October or to maintain the full conservation level till the end of September only.

Table 5. Storages adopted for studies (value in thousands of acre feet)

\begin{tabular}{lccccc}
\hline & \multicolumn{2}{c}{ Panchet } & & \multicolumn{2}{c}{ Maithon } \\
\cline { 2 - 3 } \cline { 1 - 1 } Particulars & $\begin{array}{c}\text { Storage upto } \\
\text { conservation pool }\end{array}$ & $\begin{array}{c}\text { Storage upto } \\
\text { flood level }\end{array}$ & & $\begin{array}{c}\text { Storage upto } \\
\text { conservation pool }\end{array}$ & $\begin{array}{c}\text { Storage upto } \\
\text { flood level }\end{array}$ \\
\hline $\begin{array}{l}\text { Study 1 } \\
\text { (as at present) }\end{array}$ & 330 & 610 & 66 & 980 \\
$\begin{array}{l}\text { Study 2.1 } \\
\text { Study 2.2 }\end{array}$ & 545 & 1214 & 718 & 1110 \\
\hline
\end{tabular}

Table 6. Power generated in Dvc hydel system (in $10^{6} \mathrm{kWh}$-average for the period 1968-69 and 1972-73)

\begin{tabular}{|c|c|c|c|c|c|c|c|}
\hline \multicolumn{5}{|c|}{ Average obtained } & \multicolumn{3}{|c|}{ Simulated results } \\
\hline Month & Maithon & Panchet & Tilaiya & Total & Study & $\begin{array}{c}\text { Study } \\
2 \cdot 1\end{array}$ & $\begin{array}{c}\text { Study } \\
2 \cdot 2\end{array}$ \\
\hline June & $10 \cdot 1$ & $8 \cdot 4$ & 0.5 & $19 \cdot 0$ & $10 \cdot 5$ & $11 \cdot 3$ & $13 \cdot 6$ \\
\hline July & $24 \cdot 1$ & $21 \cdot 3$ & $1 \cdot 3$ & 46.7 & $30 \cdot 6$ & $29 \cdot 5$ & $31 \cdot 9$ \\
\hline Aug. & $22 \cdot 9$ & $25 \cdot 6$ & $1 \cdot 7$ & $50 \cdot 2$ & 57.8 & $55 \cdot 0$ & $55 \cdot 8$ \\
\hline Sept. & $26 \cdot 6$ & $25 \cdot 1$ & $2 \cdot 1$ & 53.8 & $62 \cdot 2$ & $65 \cdot 3$ & $64 \cdot 2$ \\
\hline Oct. & $23 \cdot 7$ & $22 \cdot 2$ & 1.4 & $47 \cdot 3$ & $28 \cdot 2$ & $37 \cdot 1$ & $45 \cdot 9$ \\
\hline Nov. & 6.7 & $2 \cdot 8$ & $1 \cdot 6$ & $11 \cdot 2$ & 5.9 & 6.9 & $7 \cdot 7+$ \\
\hline Dec. & 3.9 & $2 \cdot 1$ & 1.9 & 7.9 & 6.8 & $6 \cdot 8$ & $8 \cdot 0$ \\
\hline Jan. & $7 \cdot 5$ & $2 \cdot 4$ & 1.5 & $11 \cdot 4$ & $6 \cdot 6$ & $6 \cdot 8$ & $7 \cdot 9+$ \\
\hline Feb. & $7 \cdot 0$ & $4 \cdot 1$ & $0 \cdot 6$ & $11 \cdot 7$ & $5 \cdot 6$ & $6-0$ & $6.6+$ \\
\hline Mar. & $8 \cdot 4$ & $5 \cdot 2$ & 0.2 & 13.8 & 5.8 & $6 \cdot 7$ & $7 \cdot 1+$ \\
\hline Apr. & $3 \cdot 8$ & $2 \cdot 5$ & 0.1 & $6-4$ & $5 \cdot 7$ & $6 \cdot 3$ & $6 \cdot 8$ \\
\hline May & $2 \cdot 4$ & $2 \cdot 2$ & 0.0 & $4 \cdot 6$ & $6 \cdot 2$ & 6.9 & $7 \cdot 3$ \\
\hline Total & $147 \cdot 2$ & 123.9 & $12 \cdot 9$ & $284 \cdot 0$ & 232.9 & $244 \cdot 6$ & 262.6 \\
\hline
\end{tabular}




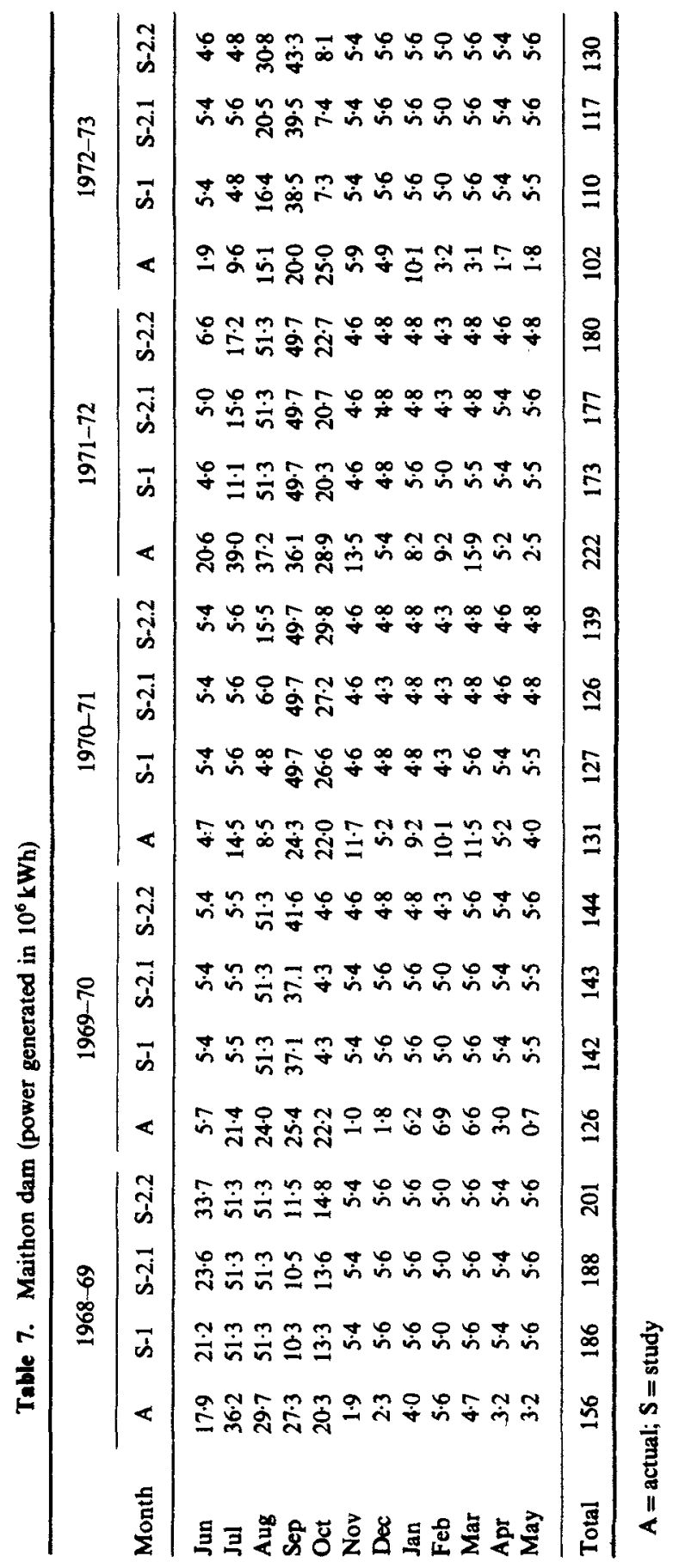




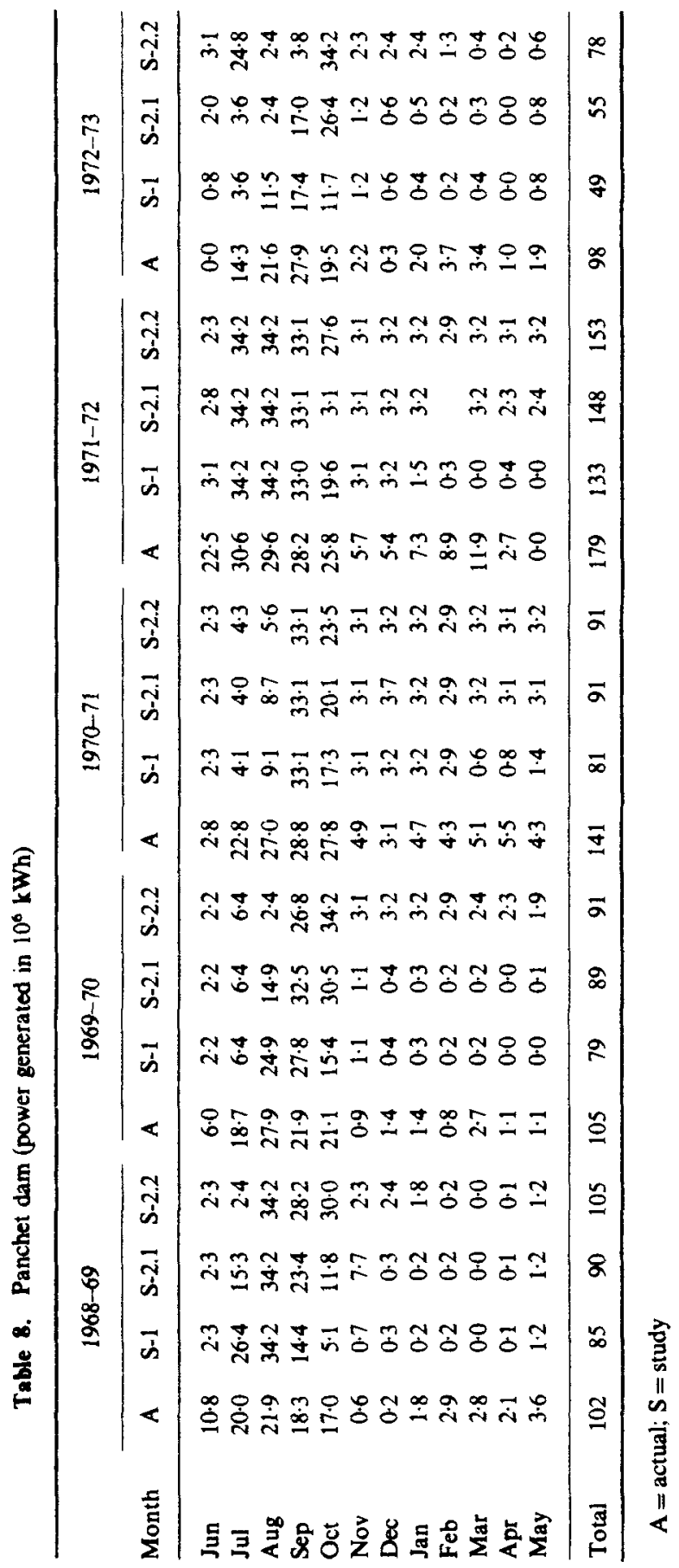


It is seen from the results of the simulation study 2 that the average monthly hydropower generation (based on actuals during the period 1968-73) will suffer in January, February and March, though on an annual basis there is no substantial decrease in hydel power generation. As the Dvc hydel system places great emphasis on peaking power to maintain the efficiency of the overall DVC power grid comprising about $1000 \mathrm{MW}$ of thermal power installation, further studies need to be carried out to ensure that hydel power generation during non-monsoon months is not affected.

In order to examine the possibility of achieving this, a third set of studies was carried out on the expanded system shown in figure 3. Table 10 summarises the various stipulations made for the four case studies. It has been assumed in all the studies that 0.201 MAF of the Tilaiya reservoir waters and 0.234 MAF of the Konar reservoir waters will be utilized for irrigation in Bihar as given in table 9. For industrial water supply, 600 cusecs throughout the year will be diverted; and for utilization above and through the Panchet reservoir, 300 cusecs will be released from the Tenughat reservoir; and $10 \%$ of the monsoon yield (July to September) from the catchments above Panchet and Maithon reserved for utilization in Bihar. In other words, supplementing the Panchet non-monsoon yield with the Tenughat reservoir releases was envisaged providing at the same time for irrigation demands in Bihar.

The success of the scheme with respect to storage yield function is generally determined by the following criteria: (a) there is no shortage in any period of the year in $75 \%$ of the number of years for which the annual operation table is prepared or in $75 \%$ of the months for which the monthly operation table is prepared; (b) in any one year/season the total irrigation shortage is not to exceed $50 \%$ of the total annual output for irrigation; and (c) in a 50-year period, the sum of all the shortages is not to exceed $150 \%$ of the firm annual yield for irrigation. Analysing the results given in table 11, it can be seen that judged from these criteria, the outcome of both the alternative plans, that is, study 3.3 and study 3.4 is almost identical even though the plan in study 3.3 has the annual inflow reduced by over half a million acre feet from that in study 3.4 (the average river flow in study 3.3 is 6306 cusecs against 7097 cusecs in study 3.4). In study 3.3, there are failures in 14 months out of the 216 months for which the operation table has been prepared. This decreases to 11 months in study $3 \cdot 4$. Both come well within
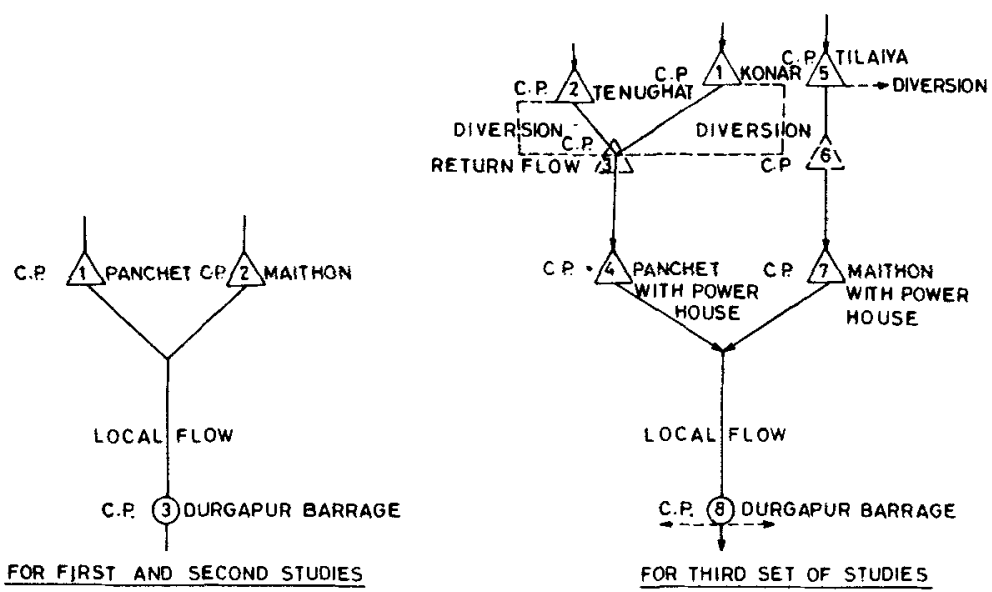

Figure 3. Schematic outline of the Damodar river basin system 
Table 9. Monthly schedule of utilization (diversion) from Tilaiya and Konar reservoirs

\begin{tabular}{lcc}
\hline Month & $\begin{array}{c}\text { Utilization from } \\
\text { Tilaya dam } \\
\left(10^{3} \text { acre } \mathrm{ft}\right)\end{array}$ & $\begin{array}{c}\text { Utilization from } \\
\text { Konar dam } \\
\left(10^{3} \text { acre } \mathrm{ft}\right)\end{array}$ \\
\hline June & 2 & 3 \\
July & 43 & 51 \\
August & 24 & 28 \\
September & 43 & 51 \\
October & 54 & 54 \\
November & 5 & 7 \\
December & 6 & 8 \\
January & 6 & 8 \\
February & 5 & 7 \\
March & 5 & 7 \\
April & 4 & 5 \\
May & 4 & 5 \\
& - & 234 \\
\hline
\end{tabular}

acceptable limits. The maximum annual shortage in any one year is 1718 cusecs in study 3.3 and 1616 cusecs in study 3.4. This has occurred in the driest year of 1966 . The average annual minimum flow being 3446 cusecs, both the alternative plans of utilization just marginally satisfy the criterion which requires that, in any one year, the total shortage should not exceed $50 \%$ of the total requirement. The third criterion requires that the sum of all shortages in a period of 50 years should not exceed $150 \%$ of the firm annual yield. In the instant study, a period of only 18 years has been considered and hence an accurate application of this criterion is difficult unless equally likely sequences for a longer period are generated and utilized. However, the average annual shortage over a period of 18 years has been obtained from the simulation studies and to compare the two plans, this can be utilized for estimating the total of shortages over a period of 50 years. In study $3 \cdot 3$, the average annual shortage in the desired flow is 123 cusecs and that in the minimum flow is 106 cusecs. These work out to 4.49 and 3.87 MAF respectively against the desired flow and minimum flow equivalent to 2.70 and $2.5 \mathrm{MAF}$. Thus, the total of shortage over a period of 50 years marginally exceeds $150 \%$ of the firm annual yield. In study $3 \cdot 4$, the corresponding average annual shortages are 103 and 93 cusecs respectively which work out to 3.76 and 3.39 MAF over a period of 50 years. These are marginally lower than the prescribed limit of 4.05 MAF and 3.75 MAF. Hence, it may be concluded that the plan of utilization envisaged in study 3.3 is slightly better than that in study 3.4 . But it has to be remembered that an average of 18 years may or may not be correct for application over a period of 50 years, especially because so great a shortage is largely due to one extremely dry year (1966); and whatever deficiencies are observed in study 3.4 are due not to shortage of water but to inadequate storage capacity.

Analysis of results in table 11 also indicates that excluding the Tilaiya, Konar and Tenughat reservoirs from the integrated operation of the Damodar system as envisaged in studies 1 and 2 will not be conducive to plans for increasing utilization of the Damodar water resources. An integrated operation of all the reservoirs on the 


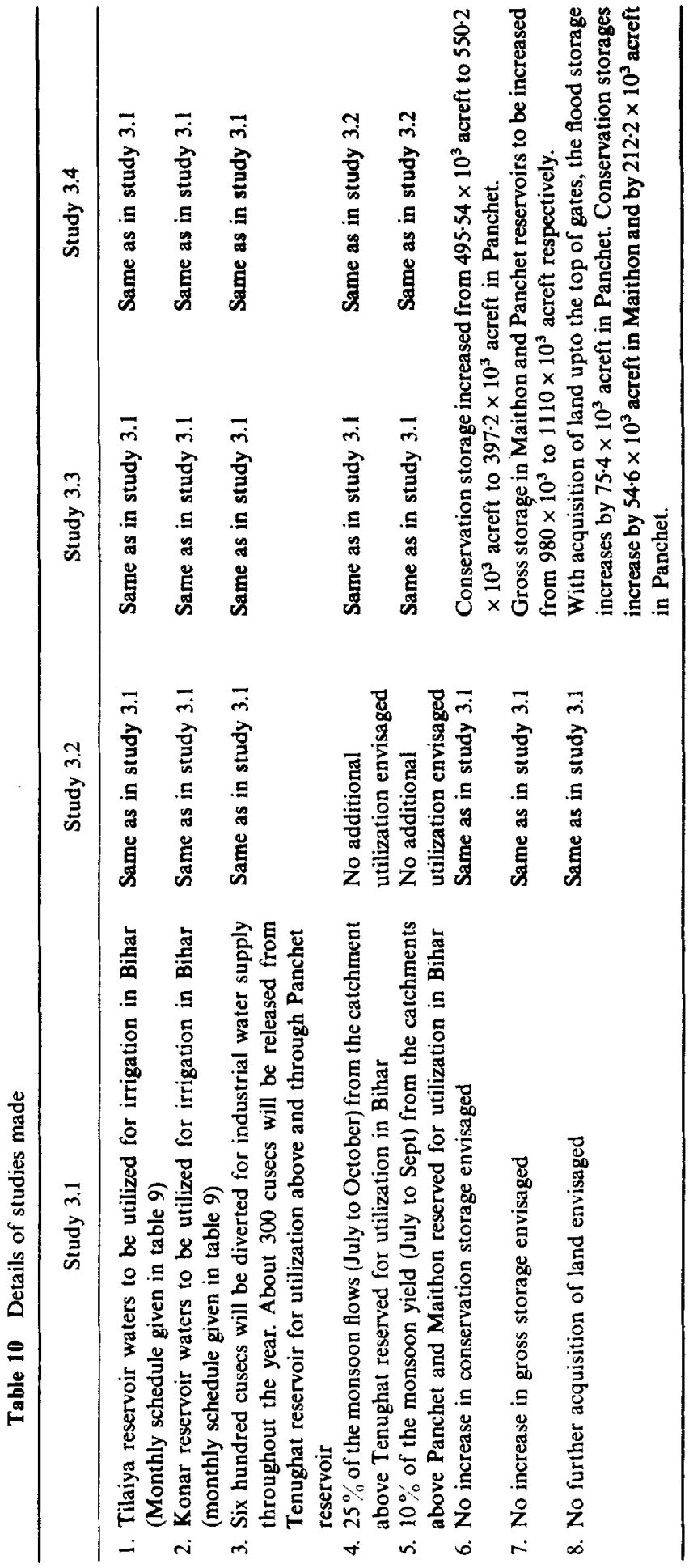




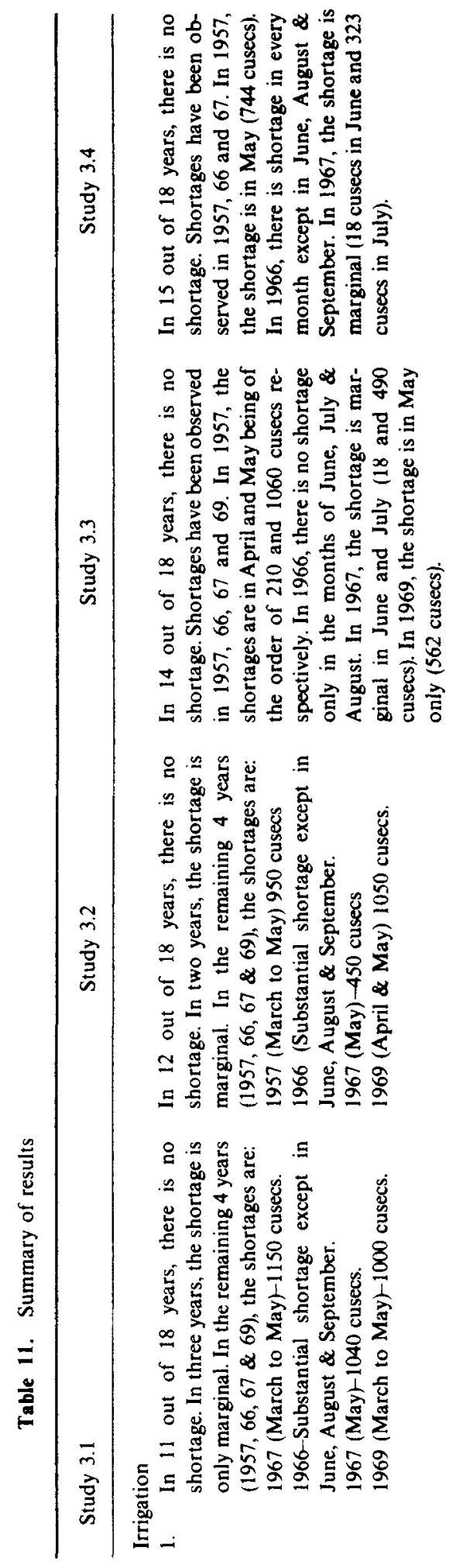

串禽总总

กํํ융윰

告

융. 웅

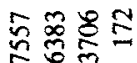

I| || ||

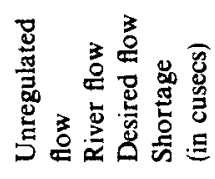




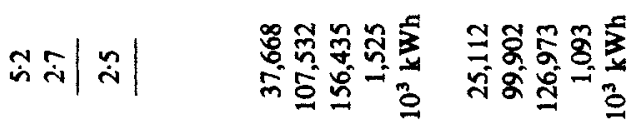

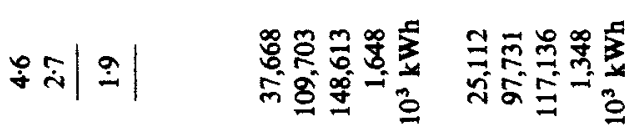

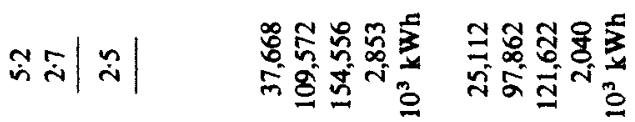

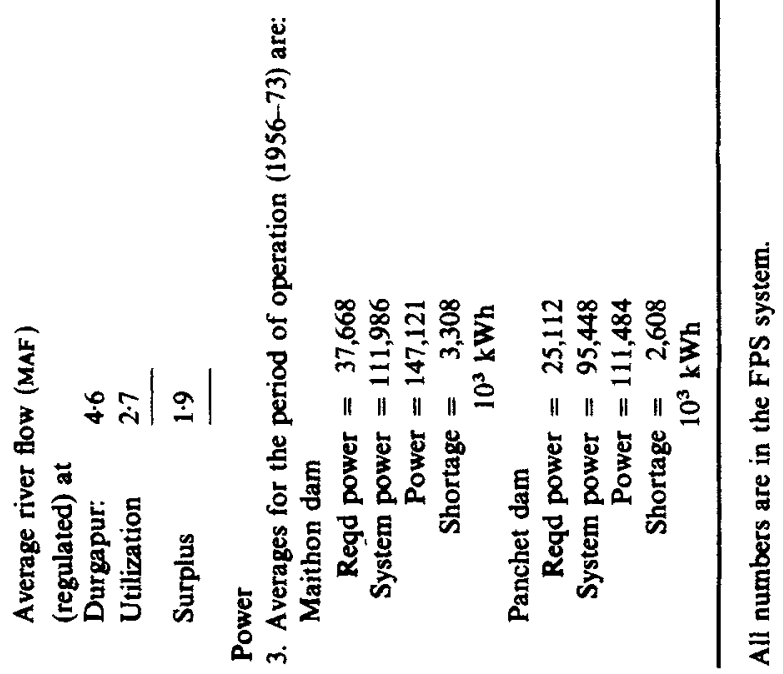


Damodar system, both existing and proposed, will help in maximisation of utilization and benefits.

\section{Conclusion}

The following conclusions emerge from the simulation model studies discussed above:

(i) Hardly $50 \%$ of the available water resources of the Damodar are being utilized at present; and even after the proposed abstraction of about half a million acre feet materialises there will be surplus water to the extent of about 1.9 MAF on an annual average. This includes the inflow contributed by the uncontrolled catchment between the Maithon and Panchet dams and the Durgapur barrage.

(ii) Since over $80-85 \%$ of the run-off occurs during the monsoon months and that too erratically, the scope of improvement in utilization is only through increased conservation storages. Thus, there is need to increase the conservation storage of the existing dams, as far as practicable, and for creating additional storage in the upper catchment. In the latter case, there should be ample provision for carry-over storage. (iii) The dams in the Damodar system should be operated as an integrated system under one unified control.

(iv) There is need for review of the existing Regulation Manual, more so because hereafter there will be utilization on the upstream of the Maithon and Panchet dams through the Konar, Tilaiya and Tenughat reservoirs. The regulation of these reservoirs should be supported by inflow forecasting to improve their efficiency.

(v) Additional dams to be constructed upstream for utilization of the Damodar waters should be planned so as to conserve the monsoon flows only. Status-quo in respect of dry-weather flows has to be maintained as the existing draws at Maithon and Panchet have limited conservation storage for meeting the demands of water supply and hydel power generation.

(vi) There are various possibilities of meeting the committed requirements of water and of increasing utilization on the upstream in Bihar. This study had limitations, inter-alia, in respect of (a) length of period for which hydrologic data were available and (b) nonavailability of particulars of works proposed to be implemented in the upper catchment.

(vii) A simulation model for the Damodar system is needed not only for long-range planning of its water resources development but also for day-to-day operation.

\section{References}

Banerjee N K 1975 Optimal operation of reservoir using system analysis: Optimisation of hydropower output from a 5-reservoir system by incremental dynamic programming; M.E. dissertation, Roorkee University Central Water Commission 1969 Regulation manual for Damodar valley reservoirs, Central Water \& Power Commission, Government of India, New Delhi

US Army Corps of Engineers 1976 HEC-3: Reservoir system analysis for conservation, Hydrologic Engineering Centre

Voorduin W L 1945 Preliminary memorandum on the unified development of the Damodar river 